\title{
EXPLORING TAX HOLIDAY POLICY IMPLEMENTATION FOR INDONESIAN INVESTMENT CLIMATE: HAS IT BEEN EFFECTIVE?
}

\author{
Mulyono Resha Dwiayu Pangesti*, Mustikasari Elia \\ University of Airlangga, Indonesia \\ "Email: reshadwiayu@gmail.com
}

\begin{abstract}
This study aims to explore the reasons for the ineffectiveness of tax holiday policy implementation in Indonesia as well as the government's strategies to improve the investment climate. This research uses exploratory study type which does not test theory or hypothesis by using preliminary survey method, conducting direct or indirect interview via email to certain informant by giving questionnaire and direct observation passively observing the field and related websites supporting statistical data in this study in depth. In testing the validity of research data used source triangulation and method triangulation. The progress that has been achieved to date in the implementation of tax holiday policy is to provide ease of bureaucracy administration and simplicity of licensing services in investing by improving coordination among government to improve foreign investors' confidence when investing in Indonesia. So technically, the implementation of tax holiday policy is quite effective in attracting foreign direct investment because it can perform the right obligations according to the regulations. In the investment point of view, tax holiday policy is not effective in attracting foreign direct investment or not becoming the main factor of investor's goal in investment. The cause of the ineffectiveness of the tax holiday policy in attracting foreign direct investment in Indonesia is another indicator that becomes an assessment among others the ease of investment licensing, infrastructure, electricity supply, investor protection, minority and tax administration. Indonesian government's strategy to improve the investment climate is through deregulation, debureaucracy, law enforcement and business certainty for investors.
\end{abstract}

\section{KEY WORDS}

Tax holiday policies, effectiveness, Indonesia investment climate, exploratory study.

One of the problems reappearing in the economic sector is that the increased global financial market uncertainty and turmoil can pose a threat to Indonesia's economic growth. Some triggers of global uncertainty are related to trade agreements and interest rate normalization policies in the United States, stock market turmoil, soaring bonds as well as the influence of the US presidential election. According to the financial records of the Financial Note (2017), the risks of economic growth of 2017 in Indonesia include: policy uncertainty and continuous financial turmoil, sluggish global trade and weakening growth in developing countries, the continuous economic slowdown in China, along with the uncertainty of the European economy adjusting to Brexit that makes an impact on Indonesian economy.

In Rixen's view (2008) in political science, a valuable work has been done to advance the competition of a country's global business, namely tax competition, and how it has become a part of our governmental institution is unintentionally created by anyone. However, what tends to be little in the political science perspective on tax competition is a normative viewpoint that allows us to understand the political and institutional responses to the phenomenon. With a few exceptions, the same thing applies to the enormous contribution of the Act regarding international taxation (AviYonah, 2000). In the world of public economy, one of the fiscal issues in tax competition is creating efficiency. Efficient tax competitions can use economic models in order to exclusively evaluate tax competitions in one dimension (Genschel, 2011). 
Taxation policy is a factor to attract investment climate in a country. There is a relationship between Corporate Income Tax and investment (e.g. Galuzka, 2013; Edame \& Oki, 2014). This effort also reinforces the government's commitment to continuously maintain the business investment climate in the middle of the steps to optimize tax revenue. One of the policies issued by the government of developing countries to attract investment is providing tax incentives in the form of tax holiday facility in which the objective of this policy is to encourage foreign and local investments in industries with a broad linkage, provide high added value and high externality, introduce new technologies, and have strategic value for the national economy.

The debate over the effectiveness of tax holiday policy implemented in Indonesia to attract the foreign investor still needs to be re-examined. This is because many studies have proven that tax holiday is not effective to attract foreign direct investment (FDI). Hayyu (2016) explained that tax holiday will never able to balance the vulnerability of economy, politics, government policy, and lack of infrastructure development but has a positive impact on economic growth and increased number of foreign investors in Indonesia. Critical notes on international experience of tax holiday implementation imply that tax holiday policies have little effect on long-term investment if compared to the government's fiscal costs (Chai \& Goyal, 2008).

According to Tajulfitri's research (2017), the assessment of tax holiday role in attracting investment in Indonesia based on tax holiday policy is a complementary policy to attract other permanent investments aimed at improving the investment climate in Indonesia. Assessing the effectiveness of the implementation of tax holiday policy can be viewed through the government's perspective on the ease and simplification of licensing services when applying for tax holiday facility. Up until now, about $40 \%$ of Indonesia's tax revenue structure is sustained by corporate income tax. It excludes administrative costs or any costs incurred due to business changes caused by the tax holiday implementation. The comparison between the costs and benefits also has to be aligned with the ease of bureaucracy, especially for the ease of business. In addition to a simpler bureaucratic assessment, there are other factors leading foreign investors to invest in Indonesia that are worth exploring.

The purpose of this study is to examine the implementation of tax holiday review period 2011-2016 in attracting foreign direct investment in Indonesia, reveal the reason for the ineffectiveness of tax holiday policy on the investment climate, and explain the role of government in encouraging investment so that the economic growth can be improved. The first and second sections of this study respectively outline the literature review and legal foundation governing the tax deduction facility. Moreover, the third section discusses the research methods used to support the validity of this study. The results and discussion are in the fourth section, while the conclusion of the research is sum up in the fifth section of this article.

\section{LITERATURE REVIEW}

Tax facility is one of tax policies. Developing countries mostly use tax facility to encourage private investment. However, according to Bird (Mansury, 2000), the effectiveness of the use of tax facilities in encouraging private investment is still questionable because there is not enough empirical evidence about the relationship between the financial factors influenced by taxation policies. These factors become the basis of the performance of a country's economic growth. Vaughan (1983: 26-28) stated that there are three fundamental things that must be considered in designing a tax policy namely efficiency, equity, and administrative cost.

In general, according to Easson (2004), the tax incentive applied to a country can be in the form of corporate income tax rate reduction for a particular activity or type of business, tax holiday, credit or tax relief for capital goods in the framework of investment, accelerated depreciation for capital goods, cost recognition that is greater than the actual cost allowed as the income deduction, decreased rate of withholding tax on the profits sent back to the 
country of origin, decreased personal income tax and/or benefits for employees, exemption or decrease of Value Added Tax (VAT) or Sales Tax (ST), decrease of Land and Building Tax (L\&B Tax), or reduction of Customs and Excise.

Capital Investment. According to Law of the Republic of Indonesia No. 25 of 2007 concerning Capital Investment (Article 1, paragraph 3), foreign direct investment is an investing activity to establish business in the territory of the Republic of Indonesia conducted by foreign investors independently or in association with domestic capital.

Definition of foreign direct investment according to Organization of Economic Cooperation and Development (OECD, 2008) is as follows:

"Foreign direct investment reflects the objective of obtaining a lasting interest by a resident entity in an economy (direct investor) in an entity resident in an economy other than that of the investor (direct investment enterprise). The lasting interest implies the existence of a long-term relationship between the direct investor and the enterprise. Direct investment involves both the initial transaction between the two entities and all subsequent capital transactions between the and among affiliated enterprises, both incorporated an unincorporated."

Attracting foreign investors across various countries is one of the effort to accelerate investment development. Furthermore, promoting foreign investment will make some important contributions to development since foreign investors provide their own capitals, transfer technology and other expertise to the countries they go in, also increase the use of modern technology. Their efforts often can increase their exports too (Sukirno, 2011:26).

Legal Foundation. According to Law No. 25 of 2007 on Capital Investment (Article 18, Paragraph 5), it is explained that:

"The exemption or deduction of Corporate Income Tax in a certain amount and time can only be given to new investment which belongs to a pioneer industry - an industry which has a broad linkage, gives a high added value and externality, introduces new technologies, and has strategic value for national economy."

The regulation of the Ministry of Finance of the Republic of Indonesia No. 103/PMK. 010/2016 regarding Provision of Corporate Income Tax Reduction Facility, stipulates that:

"Article 3 Paragraph (4) states that by considering the interests of maintaining the competitiveness of national industries and the strategic value of certain business activities, the Ministry of Finance may grant corporate income tax reduction facility with a longer term than what has been stipulated in the paragraph (2), which has been changed into a maximum of 20 years."

According to the regulation of the Head of the Investment Coordinating Board No. 19 of 2015 regarding Procedures for the Application of Corporate Income Tax Reduction Facility (Article 3, Paragraph 1) stipulates that the Application for Income Tax Reduction Facility or Tax Holiday is submitted by the taxpayer to Integrated One-Stop Service Center (Pusat Pelayanan Terpadu Satu Pintu) at Investment Coordinating Board (BKPM) completed with the documents.

\section{THEORETICAL REVIEW}

Theory of Public Policy Implementation. The theory presented by Mazmanian and Sebastier (1980) explains that there are two factors that influence the implementation of the policy, including: first, the characteristic of the problem affecting the policy (tractability of the problems), and second, the carrying capacity of the regulation consisting of the instruments that have a direct involvement in influencing the policy (ability of statute to structure implementation). The last driving factor is the "political" or environmental impact as the balancing tool in supporting the objective (non-statutory variables affecting implementations).

The following flowchart model of policy implementation process is presented to facilitate in understanding the theory of Mazmanian and Sebastier (1980).

The thought expressed by Mazmanian and Sebastier (1980) considers that the implementation is effective if the bureaucracy of its implementation fulfills what has been 
outlined by the rule, which is through the implementer's guidance or technical guidance. Therefore, the top down model introduced by this theory is the most advanced one.

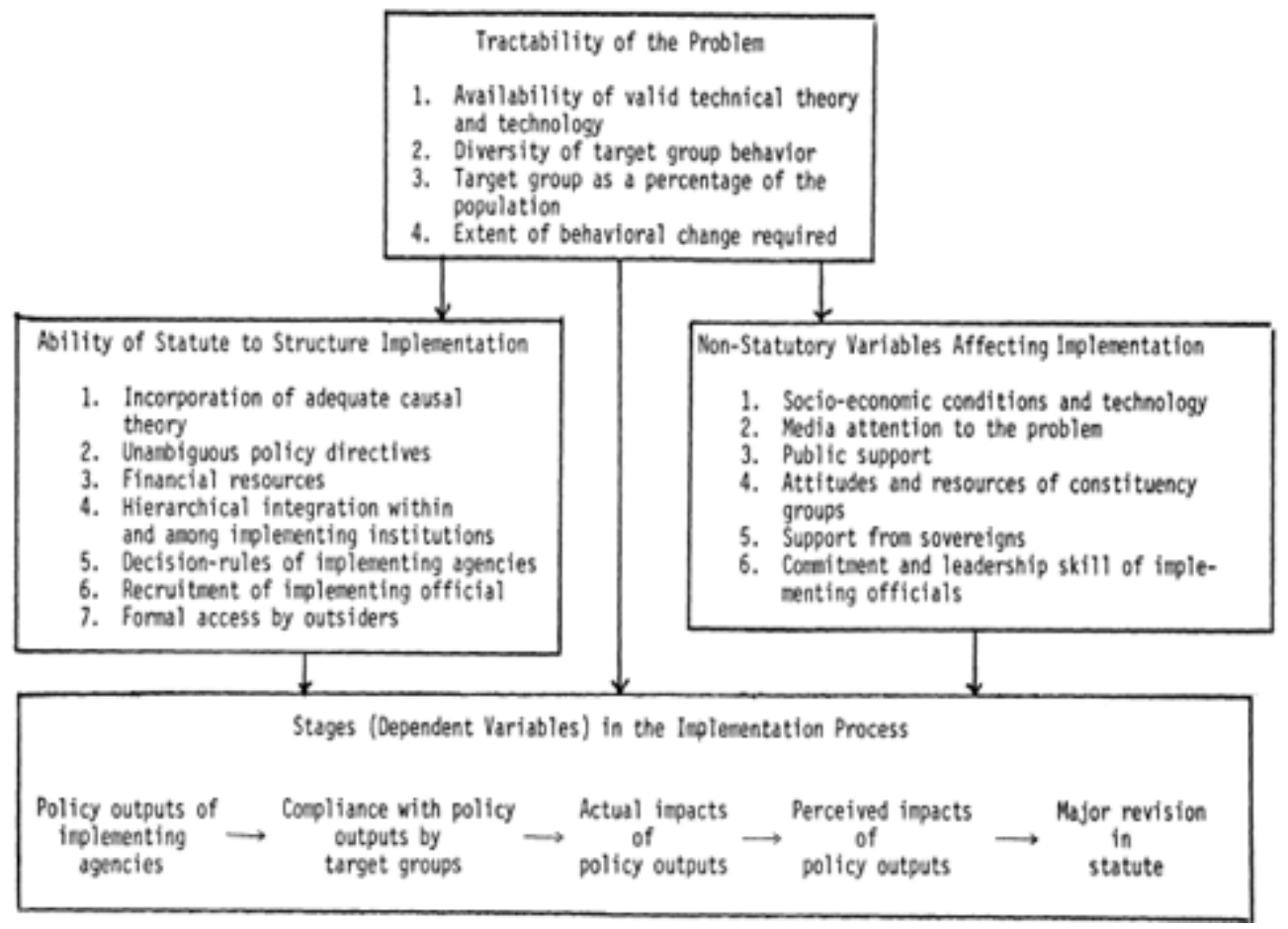

Source: Conceptual Framework of Mazmanian and Sebastier (1980)

Figure 1 - Model of Policy Implementation Process

If associated with the theory of public policy implementation (Mazmanian and Sebastier, 1980) that is used in research of assessment started from the characteristics of problems, the carrying capacity of regulation, non-legal regulation affecting implementation (environment) and the implementation process of tax holiday policy.

Theory of Redundancy Incentive Costs. According to Wells (2001), the granting of tax incentives should be regarded as equivalent as direct granting of subsidies to some companies of future incentive receivers, even without incentives. Incentive cost estimates should begin with an estimated level of redundancy: first, some investors that are interested in incentives tend to receiving more than the minimum amount required to influence their decision. The increase is a form of redundancy that imposes costs on the treasury. Second, although the level of redundancy is usually measured for foreign investors only, domestic politics commonly also leads to tax holiday for domestic investors. Third, many countries offering tax holiday have difficulties to end it once they run out of certain projects (Grubert, 1998).

\section{METHODS OF RESEARCH}

One of the approaches used in this research was qualitative using interpretive paradigm. This research was clarified by a case study that was exploratory study in which Kotler and Keller (2006) explained that exploratory study is one of the research approaches used to examine something (attracting attention) that is not yet known, not yet understood or not yet well recognized. First, this research was supported by preliminary survey through supporting data in the form of the statement of Indonesian economy, then this research was aimed to analyze in more depth the perceptions of stakeholders in relation to the effectiveness of tax holiday policy implemented as promotion media to attract investment climate. Second, this research used exploratory research method based on the statement of problems focused on, that was to deepen and discover why tax holiday policy has not been 
effective in attracting foreign direct investment (FDI) in Indonesia from the standpoints of the informants that have been predetermined. Third, the study case-based exploratory approach was chosen in this research in order to answer the question of "how and why" without doing the testing of hypotheses and existing theories, in which this research explored the data that have been processed in the report of Indonesian economy by comparing the answers from the interviews with the informants. Fourth, the results obtained would be analyzed and interpreted into description without providing unilateral judgments based on the facts occurred. The last one was by using an appropriate research method which successfully led to the results as expected, that was to be able to provide in-depth overview of the exploration results on the implementation of tax holiday policy in attracting investment climate in Indonesia.

In this research, the object being studied was the preliminary survey related to tax holiday such as the regulation of law, the taxation regulation concerning tax deduction facility, the report of Central Bureau of Statistics, the report of foreign investment realization, the World Bank data, the global competitiveness report (World Economic Forum report 20162017), the report of the Ministry of Industry, the activities of pioneer industrial enterprises, the report of tax revenue and other data. The research subjects consisted of key stakeholders (policy-maker), primary stakeholders (user), and secondary stakeholders. The data were collected by preliminary survey (document review), direct and indirect interview, and direct observation. In carrying out this research, the information related to tax holiday policy for attracting foreign investment was directly identified and collected from previous supporting regulations and researches. The information was used as the preliminary material and interview guideline arrangement. It would evolve in accordance with the responses of the informants at the time of the interview. To be more comprehensive and detail, a direct observation was conducted in this research.

Some informants who support this research to be located in Jakarta were each person from Directorate General of Taxes, Investment Coordinating Board (BKPM or Badan Koordinasi Penanaman Modal), Ministry of Industry, and Fiscal Policy Agency from the side of policy-maker or government. The association of Indonesian entrepreneurs as the user involved one person and so did tax consultant. Thus, the total informant was six people. The document review conducted through Law, Regulation of Ministry of Finance, and regulation of the latest Head of Investment Coordinating Board with the support of Indonesia economic reports. The document retrieval derived from the office of Fiscal Policy Agency, the Ministry of Industry, and $B K B M$ / Investment Coordinating Board or other documents coming from other sources such as websites and scientific articles. Furthermore, the documentation review, the transcribed results of interviews transcribed, and the direct observation would be compared then taken red thread in accordance with the theme of the study. According to Basuki (2016), to check and examine the validity and reliability, some methods can be conducted, including by using data source triangulation and method triangulation, and providing research limitation that can be developed by any further researches.

\section{RESULTS AND DISCUSSION}

Overview of Indonesian Tax Incentive Policy. Indonesia fiscal position in the last few years is relatively still in good performance. There are many regulations in making fiscal deficits and government debt respectively become $3 \%$ and $60 \%$ of Gross Domestic Product (OECD, 2016). The deficit figures show increasingly close to its limit in the past four years reflecting that economic growth has declined. The unstoppable one is that if external risks deteriorate significantly and transaction deficits is too great, the exchange rate is depressed due to capital outflow and monetary authorities should delay the downturn or even raise the interest rate again. One of the government's actions in overcoming the problem is by increasing investment. One of the fiscal policies taken by the government is tax incentive policy.

Tax incentive policy is one of the important frameworks created by the government of Indonesia to stimulate a conducive investment environment for sectors that have a change 
value for the environment. One of the targets being the government's attention in providing tax incentives is the industrial sectors which is one of the main driving forces in a country's economy. Investment activities not only transfer capital and goods, but also have an important role to play a major national economic development, transfer science, expand employment, develop industries that are capable of substituting import requirements to save foreign exchange, encourage non-oil exports to generate, transfer technologies, develop infrastructure and be able to improve disadvantaged areas. Tax incentives have been widely used in various countries including Indonesia because tax incentives are still believed to be able to provide stimulus to investment climate in Indonesia.

Law No.25 of 2007 regarding Capital Investment explains that both local and foreign investment can boost economic development and realize the welfare of society in a competitive economic system. The government's target is that there will be many new investments so that numerous employment can be created. In the field of taxation, tax incentives have been commonly used for developing countries in the world, including Indonesia. One of the types of tax incentives offered by the government of Indonesia is tax holiday or in Indonesian called as penghapusan pajak. The existence of tax incentives in the form of tax holiday facility is not as the main policy in stimulating investment climate in Indonesia.

"So, it should be known that the function of tax incentives, according to the economic theory of tax incentives, is to eliminate or avoid market failure, particularly with positive externalities. For the instance, a company has a greater benefit than the private benefit so that the company must get remuneration or return from the government because it does not include in daily transaction so that tax incentives are required." (Staff of Cooperation and Public Relation of PP2, Directorate General of Taxes (DJP).

As explained by Sari et al. (2015), there are two factors why tax holiday policy is implemented in Indonesia. The first is that Indonesia needs a fiscal policy support to attract foreign investors and the second is the business competition factor in attracting investment. In addition, nowadays, Indonesia has four factors to support the sustainability of foreign investments. The four factors are the large number of population, the relatively low labor costs, the availability of wider land and resources. Therefore, tax holiday policy is expected to attract foreign investment in Indonesia.

Until early 2017, according to the data from the Ministry of Industry (2017), there have been five of eleven companies getting tax holiday approval while the rest are advised to follow the tax incentive program of tax allowance with the investment amount of 38.5 trillion rupiah. Table 1 is a list of recipients of tax incentive facilities in the form of tax holiday.

Table 1 - List of Companies Receiving Tax Holiday Facility

\begin{tabular}{|c|c|c|}
\hline No. & Company Name & Investment Value (Rupiah) \\
\hline 1. & PT Ogan Komering llir Pulp \& Paper Mills Tbk. & 29 Trillion \\
\hline 2. & PT Unilever Cleochemical Indonesia Tbk. & 1,15 Trillion \\
\hline 3. & PT Petrokimia Butadiene Indonesia Tbk. & 1,3 Trillion \\
\hline 4. & PT Synthetic Rubber Indonesia & 4,6 Trillion \\
\hline 5. & PT Energi Sejahtera Mas & 2,8 Trillion \\
\hline
\end{tabular}

Source: The Ministry of Industry (2017).

Mechanism of Tax Holiday Facility Application. Under the taxation laws of Indonesia, companies is treated equally with Indonesian citizens in the case of tax purposes based on the establishment of the company or place of business in Indonesia. Thus, if there is any foreign company conducting business activity through permanent establishment (PE) in Indonesia, it generally will bear the same tax obligation as a Taxpayer.

The Regulation of PMK No.103/PMK 0.10/2016 stipulates that the requirements of applying for tax holiday facility are outlined as follows:

1. The applicant is a Taxpayer;

2. The minimum investment is 1 Trillion Rupiah (the USD value is according to the applicable exchange rate when applying); 
3. It should meet the provisions of the ratio of capital and debt;

4. It should place funds in Indonesian banking at least $10 \%$ of the total investment plan, and the funds cannot be withdrawn prior to the commencement of investment realization;

5. It must be a legal entity of Indonesia and its enforcement should be established on or after August 15, 2011;

6. The procedure for filing tax holiday facility has been simplified in which the applicant can file it to BKPM, with the processing time of 25 days in Investment Coordinating Board and 20 days in the Ministry of Finance. Thus, it has 45 working days;

7. In case the application of tax holiday facility by the Taxpayer is rejected, the Tax Payer may get tax allowance facility as long as it meets the scope of business.

After obtaining a proposal from the Investment Coordinating Board, the Directorate General of Taxes assigns the Verification Committee to do verification and the research on the regulatory requirements of $P M K 103$ / PMK 0.10 / 2016 as well as other strategic studies aimed at the Taxpayer giving impact on national economy. The Verification Committee reviews the Tax Payer applying tax holiday facility. The requirements that should be met include application forms, copies of official documents, amendments and approvals, principal licenses, investment value descriptions and management signatures, and seals. Figure 2 describes the mechanism for filing tax holiday facility.

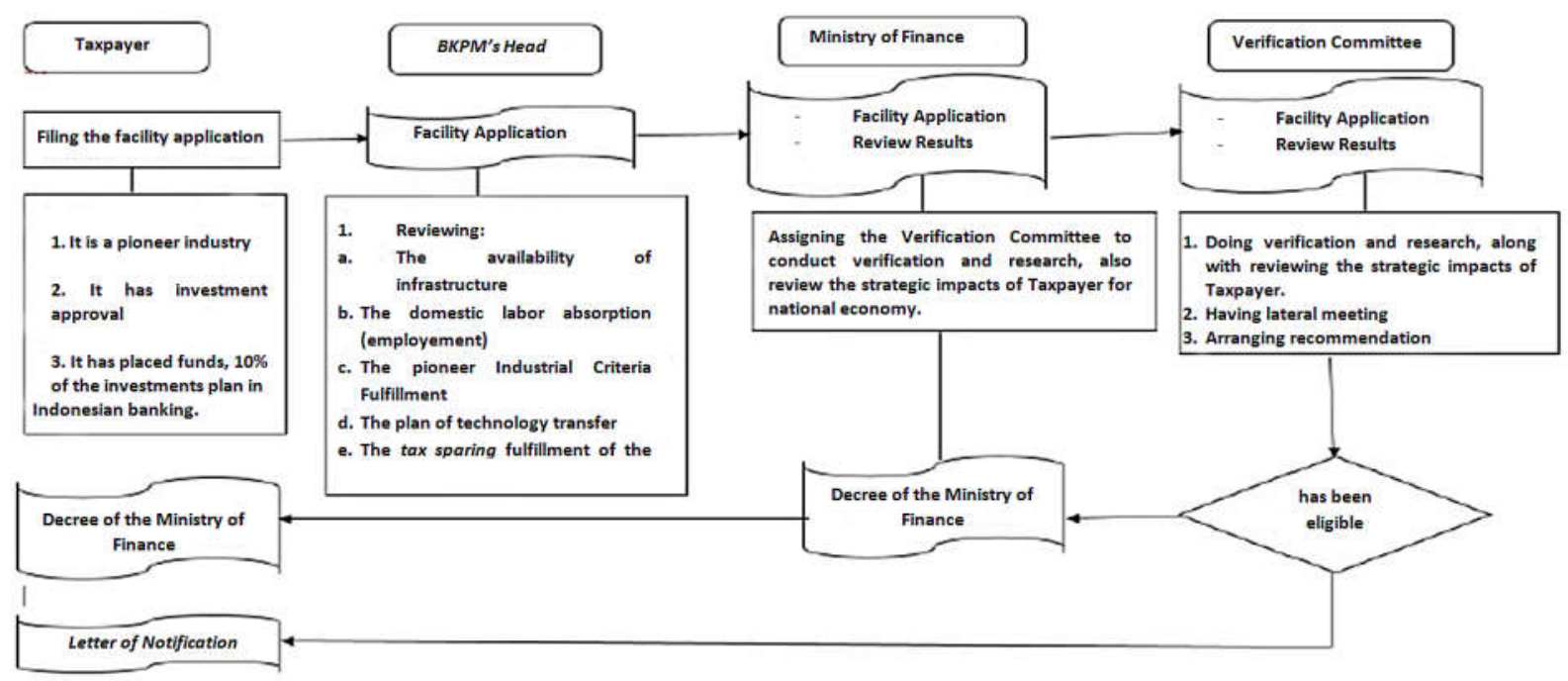

Source: Investment Coordinating Board (2016)

Figure 2 - Mechanism of Tax Holiday Facility Application

For taxpayers who are eligible for the tax holiday, the Verification Committee will prepare a recommendation to be issued by Decree of the Ministry of Finance stating that the taxpayers are entitled to a tax holiday, and they should meet the obligations of prescribed rules. The stages that must be passed to obtain a tax holiday begin with the filing of tax holiday until the enactment of Decree of the Ministry of Finance, spending about 45 days of processing right after the filing of the documents is declared by the BKPM (Investment Coordinating Board). Then, the Investment Coordinating Board will submit a proposal to the Ministry of Finance which in this case has appointed a team of Verification Committee consisting of representatives of Directorate General of Taxes (DJP), Fiscal Policy Agency $(B K F)$, the Ministry of Industry, Investment Coordinating Board, and the Coordinating Ministry of Economic Affairs to make a decision to the taxpayers who are entitled to tax incentives in the form of tax holiday if they have met the requirements without consulting to the President and the Coordinating Ministry of Economic Affairs. This is a new form of policy cutting off the bureaucracy so that the acceleration of documentation can be done efficiently. 
"Currently, according to the latest regulation, the Ministry of Industry is completely not involved and included in the proposed tax holiday regulation. Companies can no longer propose to the Ministry of Industry. The proposing now is through BKPM (Investment Coordinating Board) and we are involved in the discussion. If it has entered into and processed in BKPM, we just took a part in the discussion or the so called Lateral Meeting. So, Lateral Meeting consists of the Ministry of Finance, BKPM, the Ministry of Finance, and the involved Technical Ministry. After that, the verification committee of each representative is set up" (Head of Tariff and Tax Sub-Division, the Ministry of Industry).

Assessment of Tax Holiday Effectiveness for Indonesia Investment Climate. The importance of tax incentives in the form of tax holiday is aimed at spurring the investment climate in Indonesia and the primary target is foreign investors for the increased economic growth in Indonesia. Hence, the government has designed tax incentive policy, one of which is tax holiday policy for pioneer industries that have been stipulated in the Regulation of the Ministry of Finance. The policy assessment of the current economic policy framework is improving rapidly. Until now, there is no specific regulation governing the tax holiday facility or in the realm of the Investment Law. Table 2 shows the realization of foreign and local investments in the period of 2011-2016.

Table 2 - Domestic and Foreign Investment Realization of 2011-2016

\begin{tabular}{|c|c|c|c|c|}
\hline \multirow{2}{*}{ Year } & \multirow{2}{*}{$\begin{array}{c}\text { Domestic Investment } \\
\text { (Trillion Rp) }\end{array}$} & \multirow{2}{*}{$\begin{array}{c}\text { Foreign Investment } \\
\text { (million USD) }\end{array}$} & \multicolumn{2}{|c|}{ Growth (YoY) (\%) } \\
\cline { 3 - 5 } & 76,0 & $19.474,2$ & Domestic Investment & Foreign Investment \\
\hline 2011 & 92.2 & $24.564,7$ & 25,4 & 20.1 \\
\hline 2012 & 128,2 & $28.617,5$ & 21,3 & 26,1 \\
\hline 2013 & 156,1 & $28.529,7$ & 21,8 & 16,5 \\
\hline 2014 & 179,4 & $29.275,9$ & 14,9 & $-0,3$ \\
\hline 2015 & 216,3 & $36.777,8$ & 25,8 & $-5,5$ \\
\hline 2016 & & &
\end{tabular}

Source: Investment Coordinating Board (2016).

Based on the previous explanation on the investment realization growth in Indonesia, the implementation of tax holiday conducted by the government is actually a political policy, meaning that there still has weakness until now because the value of investment has a negative effect on foreign investment. Only certain groups have an important effect as the actors or policy entrepreneurs in forming tax holiday policy. The groups with a strong influence in the policy of tax holiday facility actually belong to large capital investors that are based on personal interests, economic interests and private profits. Furthermore, they are able to lobby, make an influence, and encourage the government (both legislative and executive bodies) in order to plan and implement tax incentives in the form of tax holiday for the benefit of the groups. That is, the government gives the red carpet signal through tax incentive policy in order to attract investors. The further explanation by a tax consultant is as follows:

"The level of effectiveness to attract investments or investors also is not influential. Without or no tax holiday, there is no influence. Theoretically, tax incentive policy can cause distortions for making investment decision depending on the tax incentives offered by the government. Practically, tax incentives will lead to ineffectiveness and inefficiency. It is not effective because tax considerations are rarely taken into account in Foreign Direct Investment (FDI)" (Tax Consultant, DDTC).

This was reinforced by the explanation of the Association of Indonesian Entrepreneurs as the representative of entrepreneurs in Indonesia as follows:

"Ya, I think it is less effective. In my view, the value of investments is too large, that is a trillion with a minimum investment of 500 billion. Given the current state of the situation, it is rather difficult to attract investment although administrative improvement has been made such as accelerated licensing services, Integrated One-Stop Services (PTSP), simplification but with severe conditions. One trillion is relative" (The Representative of Finance and Taxation Division, Apindo). 
The government as a policy-maker also gave a view on tax holiday policies in attracting investment climate in Indonesia today:

"In my opinion, it is quite effective, depending on the psychological condition of investors. Yap, because they do not only pay attention to the facilities, but also the human resource, the natural resources, the raw materials, and the infrastructure which is important the most. The wage of workers also becomes a concern of government policy towards the industries. Therefore, I think it is quite helpful but it is not a major factor in attracting investment in Indonesia. Actually, there is still much that must be seen by investors if they want to invest." (Head of Tariff and Tax Sub-Division, the Ministry of Industry)

"Talking about the effectiveness of the facility, it is not the main factor, it is the umpteenth factor. However, indeed for the entrepreneurs, the only one that can be accounted is the tax. Then, they think it can be considered although it is not the primary. Nevertheless, we ourselves cannot guarantee. If we provide facility to taxpayers, and they don't want to invest, that will be our difficulty. So, the incentive is aimed to attract the FDI." (Head of Taxation Division and Non-Tax State Revenue (PNPB II), Fiscal Policy Agency (BKF).

"Overall, I think that the policy can be quite effective even though the demand is small because it is just a pro-investment policy through tax incentives. There must be other factors to be the consideration of investors in investing, particularly the readiness of the destination country in providing an offer to investors by giving ease of licensing services" (Staff of investment deregulation, Investment Coordinanting Board (BKPM).

Effectiveness through Labor Absorption (Employment) in Indonesia. The current government's expectation of using tax holiday policy is actually to be able to increase the labor absorption in the industrial sector that has been determined. However, the implementation in the field has not run maximally. Evidently, there were many investors interested in using tax holiday facility but could not meet a number of requirements that have been determined. Assessing the effectiveness of Indonesian investment climate can be determined by the level of the domestic labor absorption, which is by comparing the amount of domestic and foreign investments. Since 2011 till 2016, with the existence of new employments or job vocations, there had been created 21,834 projects with a total realization of 453,4 trillion rupiah or $76,2 \%$ of the target of investment realization. The most dominant number of realizations belonged to foreign investment of 309.623 trillion rupiah. Laborintensive investment (textile and footwear) had successfully absorbed direct labors of 153,400 people or about $16 \%$ of the new vocations created. From the investors, the projected contribution could reach 1.25 million jobs every year.

"Actually, according to the reporting data of labor absorption, labor-intensive industries are eight times more effective in absorbing labor than other investment sectors that is 17,900 direct workers per 1 trillion rupiah of investment realization. In other words, the pioneer industries regulated to improve investment climate through tax holiday policies do not effectively absorb direct labor" (Deputy of Control and Implementation Division, Investment Coordinating Board (BKPM).

The tax holiday policy does not target labor-intensive industries such as the tax holiday policy regulated in Regulation of the Ministry of Finance No. 103/ PMK.010/ 2016, stating that pioneer industry target does not focus on certain sectors of labor-intensive industries such as the upstream industry, and the industry of telecommunication, information and communication. Tax holiday policy currently is not the primary priority in absorbing labor as it aims to assist the government in developing national economy using the latest technology and acceleration of infrastructure development under the terms described in the regulation.

Effectiveness through Indonesia Bureaucratic Administration. According to the idea presented by Mazmanian and Sebastier (1980), the implementation of the policy is effective if the bureaucracy of its realization meets what the rules have stipulated through the implementer's guidance and technical guidance. Regulations and its implementation can be carried out appropriately and on target. The assessment covers the issues being studied, regulatory support, non-legal carrying capacity and the policy implementation process that proceeds in accordance with the technical system through regulations. 
As for the bureaucratic reforms, the existence of legal umbrella for tax incentives is a form of insistence from the investors to get a relief on companies that plan to stand with the assumption to free them from the imposition of income tax. Tax holiday policy is regulated under the Investment Law No.25 of 2007 that is not in line with the Law of Income Tax No.7 of 1983 , which is then also changed to Law No.36 of 2008, in which there is no other Article but Article $31 \mathrm{~A}$ mentioning that there is tax deduction facility in the form of tax holiday. Under the Investment Law, there has been many regulations governing on the form of facilities that can be used, the requirements of investment, the criteria of investors that are eligible for a tax holiday. However, the tax holiday policy cannot be applied because, in the Investment Law, there is no authority to regulate the form of tax facility so that supporting regulations are very necessary that is by the issuance of Regulations of the Ministry of Finance in the form of tax deduction facilities in certain fields. The point of view of legal uncertainty have an impact on the effectiveness as expressed by the Association of Indonesian Entrepreneurs as follows:

"If the legal certainty is still contradictory, then do not expect that tax holiday policy can effectively attract foreign investment to Indonesia. The tax regulations related to tax holiday must be firm and meet the requirements of tax holiday so that it can be effective and result in legal certainty" (Representative of Finance and Taxation Division, Apindo).

The other one becoming the assessing indicator of the success of tax holiday policy implementation is the spotlight of tax holiday facility application, which is the easier stage of bureaucracy for now. To date, the progress that has been achieved in providing ease of tax holiday policy consists of improving the coordination between government agencies such as Fiscal Policy Agency, Directorate General of Taxation, the Ministry of Industry, and Investment Coordinating Board that are mutually integrated to increase foreign investor confidence for investing in Indonesia so that business actors do not need to submit notices separately to various institutions when they have solved the administrative problems in one of the institutions. That is why the Integrated One-Stop Service Center is finally established under the Investment Coordinating Board (BKPM).

Furthermore, the role of the government has made many improvements such as carrying out deregulation by reducing the number and types of duplication permits, regulatory harmonization, regulatory/policy consistency, and the simplification of licensing to reduce the requirements of licensing, clear SOP or SLA, delegation of authority to Integrated One-Stop Services (place, form, time, cost), licensing and non-licensing services through electronic systems, law enforcement, and business certainty.

In addition to the improved bureaucratic system and ease of licensing service for investing, another thing to do by the Capital Market Coordinating Board is through marketing strategy that includes five proactive steps in attracting investment interests, consisting of establishing Special Teams of Marketing (Marketing officer), making proactive investment marketing through One on One Meeting and Business Meeting, facilitating investors by providing information, consultation, and ease of obtaining license up to the regional level, cooperating with Banks in the focus of investment marketing, and strengthening coordination with the Ambassador Representative as well as domestic and foreign stakeholders.

In the stage of bureaucracy, tax holiday policy always experience improvement with simplicity and easiness. However, this can effectively run if the regulations are still contradictory to each other because there is no special law on tax holiday policy. The number of recipients of the tax holiday facility in Indonesia is still very small if compared to the recipients of the tax allowance facility. The other assessment in addition to the tax incentives given is the ease of establishing business in Indonesia, which has received a fairly serious assessment from investors as the capital owners.

Assessment of Redundancy Incentive Fee on Tax Holiday Policy. In knowing the effectiveness, it is not sufficient for policy-makers to only view from the side of tax holiday benefits in attracting investment. Since previous studies have concluded that some investors at least tend to be sensitive to tax incentives, the benefits related to attracting such firms should be considered against the cost of the tax holiday program. The previous studies have not much considered on the costs, which are calculated after utilizing the facility. In the 
context of tax incentive grant with a long range of time, an unhealthy competition among new investors may occur. This actually does not influence the amount of investments. Instead, the results will impose other redundancy sources. As disclosed on the opinion of the tax consultant as follows:

"In the context of global competitiveness, the field of tax competition becomes a signal between the government and investors. Tax incentives can be an option although not as the main factor of tax. But, in general, IMF and World Bank actually do not advise the developing countries to provide tax incentives for foreign investors. OECD and G20 prevent the occurrence of unhealthy competition for the countries that provide tax incentives" (A Tax Consultant, DDTC).

If noticed, tax holiday policies also increase administrative issues because tax officials usually do not monitor the company's records/books during the period when the company is free from tax. As the consequence, the occurrence of asset purchases, depreciation charges, and other accounts can be manipulated during the period of tax holiday in order to reduce the reported income and also the tax after the exemption. Theoretically, the tax authorities can determine the price of "arm's length"and reallocate profits between taxes and the other parts that can not be shared from the company. In practice, it is mostly proven impossible. When tax administrators attempt to overcome the issue, they must use slightly arbitrary rules. It results in the increased perception of bureaucracy and lack of transparency that hinders investments.

More importantly, the ease of providing incentives can be imposed on other costs but policy-makers tend to ignore them. The more difficult reforms will have a greater impact on foreign investments. This will give constraints to the investors such as closed industries, domestic content requirements, domestic ownership requirements, reduced bureaucratic barriers, improved infrastructure, and so on. Policy improvements through deregulation can rationalize the rule by eliminating the irrelevant duplication or redundancy of regulations on tax holiday policies.

\section{CONCLUSION}

Tax holiday policy is not a major factor in attracting foreign investment in Indonesia. Instead, it is only a complementary factor that can be considered by investors in determining investment decisions. At the bureaucratic stage to attract foreign investment climate, the government always make improvements yet the weakness emerging is that there is no special tax incentive Law. There are other factors that investors consider in investing, including easy start-up, minority investor protection, availability of electricity, adequate infrastructure, tax administration and other factors.

In order to increase the foreign investor's interest in investing in Indonesia, the government of Indonesia plays a role in setting strategies to create a more conducive investment climate by mean of deregulation, that is by the reduced number and types of duplication license, regulatory harmonization, and Regulation or policy consistency, debureaucratization with simplification of licensing to reduce licensing requirements, clear SOP and SLA, delegation of authority to Integrated One-Stop Services (place, form, time, cost), licensing and non-licensing services through electronic systems, law enforcement, and business certainty.

Tax holiday policies also increase administrative issues because tax officials usually do not monitor the company's records/books during the period when the company is free from tax. As the consequence, the occurrence of asset purchases, depreciation charges, and other accounts can be manipulated during the period of tax holiday in order to reduce the reported income and also the tax after the exemption. Further research can be conducted within the framework of improving the effectiveness of tax holiday facility, i.e. calculating the degree of return with regard to the given facility toward enterprises' obligations, whether or not it has satisfied the efficiency. Tax holiday tends to create distortion when investors ask for too many demands. In that case, the government should conduct an evaluation on such tax incentive policy in order to improve the national development. 


\section{REFERENCES}

1. AviYonah, R. S. (2000). Globalization, tax competition, and the fiscal crisis of the welfare state. Harvard law review, 1573-1676.

2. Basuki. (2016). Metode Penelitian Akuntansi dan Manajemen Berbasis Studi Kasus. Surabaya: Airlangga University Press.

3. Chai, J., \& Goyal, R. (2008). Tax Concessions and Foreign Direct Investmentin the Eastern Caribbean Currency Union: International Monetary Fund.

4. Easson, A. J. (2004). Tax incentives for foreign direct investment. London: Kluwer Law International.

5. Edame, G. E., \& Okoi, W. W. (2014). The impact of taxation on investment and economic development in Nigeria. Academic Journal of Interdisciplinary Studies, 3(4), 209.

6. Gałuszka, J. (2013). The Fiscal Union as a Remedy For the economic and Financial Crisis in the European Union. Equilibrium. Quarterly Journal of Economics and Economic Policy, 8(1), 49-67.

7. Genschel, P., \& Schwarz, P. (2011). Tax competition: a literature review. Socio-Economic Review, 9(2), 339-370. Economic Journal, 59, 4.

8. Hayyu, N.N. (2016). Pengaruh Tax Holiday Terhadap Foreigen Direct Invesment Dan Pertumbuhan Ekonomi Indonesia Periode 1983-2014 (Tax Holiday Effect Of Foreign Direct Investment And Economic Growth In Indonesia Period 1983-2014). Jurnal Ekonomi dan Studi Pembangunan 9 (1), 89-96.

9. Kotler, P., \& Keller, K. L. (2006). Marketing Management: Pearson Education Ltd. New Jersey.

10. Mansury. (2000). Kebijakan Perpajakan. Jakarta: Yayasan Pengembangan dan Penyebaran Pengetahuan Perpajakan

11. Mazmanian, D. \& Sabatier, P. (1980). Conceptual framework. Policy Studies Journal, 538-560.

12. Organization of Economic Co-operation and Development (OECD). (2008). An Overview of Foreign Direct Investment Concepts. OECD Benchmark Definition of Foreign Direct Investment, Edisi IV

13. Organization of Economic Co-operation and Development (OECD). (2016). OECD Economic Survey: Indonesia 2016

14. Republik Indonesia. Nota Keuangan Beserta Rancangan Anggaran Pendapatan Dan Belanja Negara Tahun Anggaran 2017. Jakarta

15. Republik Indonesia. Peraturan Kepala Badan Koordinasi Penanaman Modal Nomor 19 Tahun 2015 tentang Tata Cara Permohonan Fasilitas Pengurangan Pajak Penghasilan Badan. Jakarta.

16. Republik Indonesia. Peraturan Menteri Keuangan Nomor 103/PMK.010/2016 Tentang Pemberian Fasilitas Pengurangan Pajak Penghasilan Badan. Jakarta

17. Republik Indonesia. Undang - Undang Nomor 25 Tahun 2007 Tentang Penanaman Modal. Jakarta

18. Rixen, T. (2008). The political economy of international tax governance: Springer.

19. Sari, N., Dewi, M. S., \& Sun, Y. (2015). Indonesia: The Effect of Tax Holiday on Economic Growth Related to Foreign Investment. Procedia-Social and Behavioral Sciences, 211, 1008-1015.

20. Sukirno, S. (2011). Makroekonomi Teori Pengantar (Edisi Ketiga ed.). Jakarta: Rajawali Pers.

21. Tajulfitri, S. S. (2017). Role of Tax Holiday In Attracting Investment In Indonesia. Cendekia Niaga, 1(1), 59-66.

22. Vaughan, R. J. (1983). Guidelines for Developing A State Tax Policy. Durham, N.C: Duke Press Policy Study.

23. Wells, L.T. (Ed.). (2001). Using tax incentives to compete for foreign investment: are they worth the costs? (Vol. 15). World Bank Publications. 